\title{
Use of H-1 Antihistamine in Dermatology: More than Itch and Urticaria Control: A Systematic Review
}

\author{
Chang-Yu Hsieh (D) · Tsen-Fang Tsai (id
}

Received: February 27, 2021 / Published online: April 12, 2021

(c) The Author(s) 2021

\section{ABSTRACT}

H-1 antihistamines are commonly used in dermatological practice for itch and urticaria control. The widespread expression of $\mathrm{H}-1$ receptor on different cells in the skin and various biologic functions of $\mathrm{H}-1$ antihistamines indicate the possible treatment potentials of $\mathrm{H}-1$ antihistamines in dermatology. A literature search was performed on PubMed and Embase, targeting articles reporting use of antihistamine for purposes other than itch and urticaria control in dermatological practice. Several off-label usages of antihistamines were identified, including alopecia, acne, Darier disease, eosinophilic dermatoses, paraneoplastic dermatoses, psoriasis, lichen nitidus, radiation dermatitis, skin dysesthesia, and cutaneous malignancies. Additional benefits were observed when $\mathrm{H}-1$ antihistamines were used either alone or in combination with other therapeutic modalities. Although various novel uses of H-1 antihistamines have been uncovered, the evidence level of most included studies is weak. Further randomized control trials are warranted to better evaluate the efficacy and

C.-Y. Hsieh · T.-F. Tsai ( $₫)$

Department of Dermatology, National Taiwan

University Hospital, Taipei, Taiwan

e-mail: tftsai@yahoo.comC.-Y. Hsieh

e-mail: allen17570@gmail.com dosage of H-1 antihistamine for dermatological disorders.

Keywords: Anti-inflammation; Dermatology; H-1 antihistamines; Off-label usages; Pleiotropic effects

\section{Key Summary Points}

In addition to itch and urticaria, dermatological applications of $\mathrm{H}-1$ antihistamines include scarring and nonscarring alopecia, acne, Darier disease, eosinophilic dermatoses, paraneoplastic dermatoses, psoriasis, lichen nitidus, radiation dermatitis, skin dysesthesia, and cutaneous malignancies. However, most applications were documented in case reports, case series, or cohort studies; thus, further randomized controlled trials are warranted to evaluate their true efficacy.

Although evidence supporting the use of $\mathrm{H}-1$ antihistamines for dermatologic purposes other than itch and urticaria control remains limited, more studies are encouraged, considering the relative low cost and safety of H-1 antihistamines. 


\section{DIGITAL FEATURSES}

This article is published with digital features, including a summary slide, to facilitate understanding of the article. To view digital features for this article, go to https://doi.org/10.6084/ m9.figshare.14319323.

\section{INTRODUCTION}

Histamine is a vasoactive chemical involved in physiologic and pathologic processes such as pruritus, inflammation, and vascular leak. Widespread expression of $\mathrm{H}-1$ receptor on a large variety of cell types in the skin was found, including mast cells, eosinophils, neutrophils, dendritic cells, macrophages, T cells, B cells, keratinocytes, endothelial cells, smooth muscle cells, and neurons [1]. Antihistamines are most known for their therapeutic effects in suppression of pruritus, typically used in urticaria and angioedema. However, other properties of antihistamines have been less explored. This article summarizes the published reports on use of antihistamines for purposes other than itch and urticaria control in dermatological practice and the possible modes of action.

\section{METHOD OF LITERATURE SEARCH}

Referenced papers published up to 6 November 2020 were identified from a search of PubMed and Embase by employing the term (antihistamines AND (skin OR dermatoses OR cutaneous OR dermatology) NOT (itch OR urticaria OR atopic)). Title and abstract of the identified articles were reviewed, and those reported using antihistamine in dermatological conditions, but not for itch and urticaria control, were included $(n=51)$. Additional relevant articles were selected from the reference lists of the retrieved papers and citations $(n=16)$. Letters and reports from academic conferences were also included when they appeared in a published work. Due to space limitations, mechanisms without proven clinical dermatologic applications were excluded, including antibacterial activity [2, 3] (e.g., mycobacterial infection [4]), antiangiogenesis [5-7], and antifibrosis [8, 9]. Besides, diseases in which the efficacy of antihistamines has not been proven in human studies were also excluded, such as keloid $[10,11]$ and cutaneous leishmaniasis $[12,13]$. Lastly, articles reporting the treatment potentials of $\mathrm{H}-2$ antihistamines in dermatology were also excluded. The full searching strategy is illustrated in Fig. 1.

This article is based on previously conducted studies and does not contain any studies with human participants or animals performed by any of the authors.

\section{MECHANISM OF H-1 ANTIHISTAMINES}

\section{Inhibition of Mast Cell and Basophil Mediator Release}

As a specific antagonist of the histamine- 1 receptor, $\mathrm{H}-1$ antihistamines could also inhibit histamine, prostaglandin D2 (PGD2), interleukin (IL)-3, 6, and 8, and tumor necrosis factor alpha (TNF- $\alpha$ ) release from mast cells and basophils $[14,15]$. In addition, high concentration of antihistamine has mast-cell-stabilizing effect [16].

\section{Effects on Eosinophil Chemotaxis}

Second-generation, nonsedative $\mathrm{H}-1$ antihistamines, including loratadine, desloratadine, terfenadine, fexofenadine, levocetirizine, and cetirizine, have all been proven to attenuate platelet-activating factor (PAF)-induced eosinophil chemotaxis and TNF- $\alpha$-induced eosinophil adherence to endothelial cells [14, 15]. Some antihistamines such as diphenhydramine, chlorpheniramine, oxatomide, and fexofenadine reverse the survival-prolonging effect of IL-5 in eosinophils by enhancing apoptosis [15].

\section{Effects on Adhesion Molecule Expression and Chemokine Release of Keratinocytes}

Intercellular adhesion molecule 1 (ICAM-1) mediates a strong adhesion between $\mathrm{T}$ cells and 


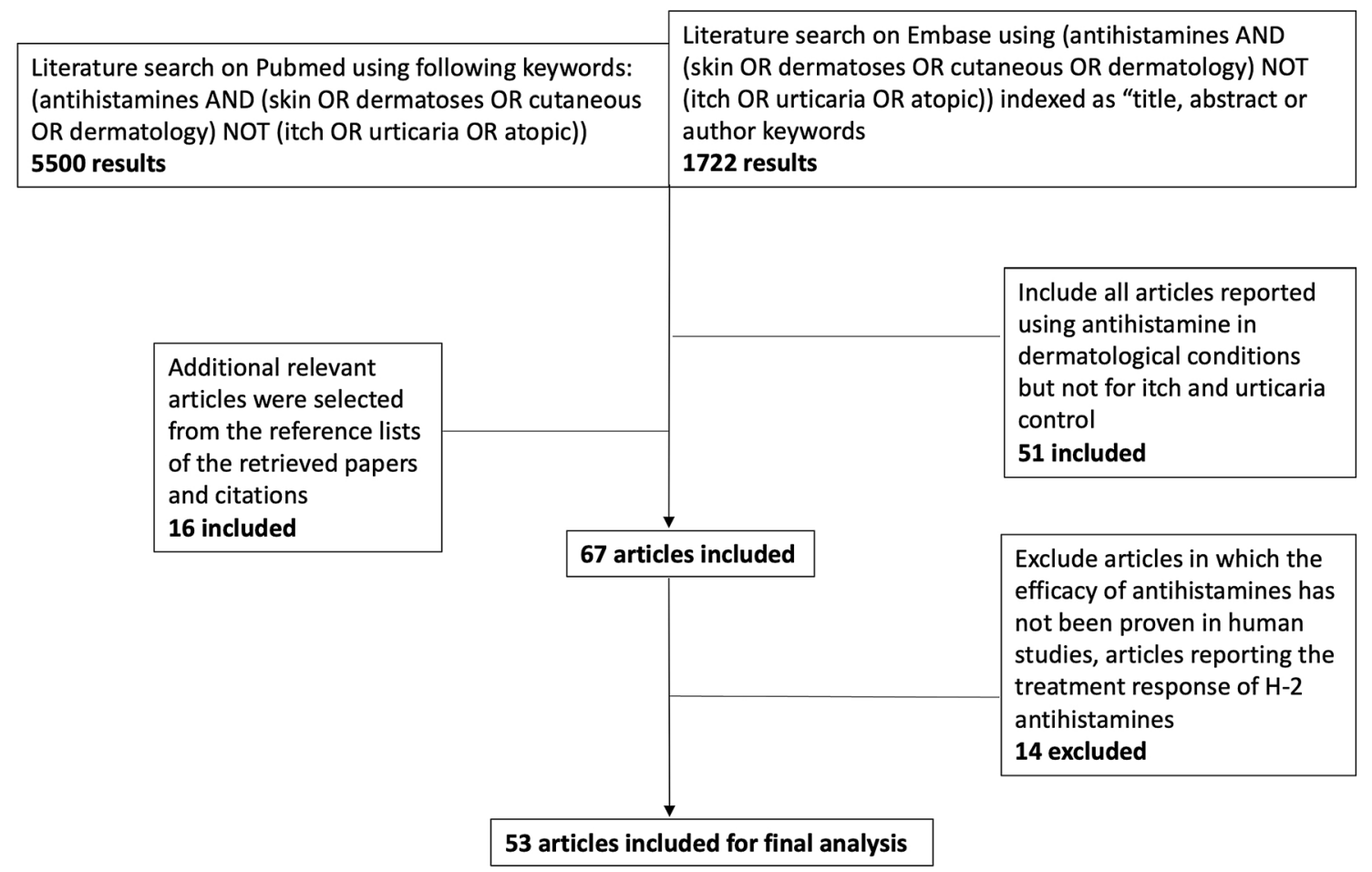

Fig. 1 Flow diagram of the literature identifcation and screening process

keratinocytes. Interferon gamma (IFN- $\gamma$ ) induces a dose-dependent release of soluble ICAM-1 molecules. Cetirizine inhibits IFN- $\gamma$-induced expression of ICAM-1, HLA-DR, and MHC class I on keratinocytes and the release of chemokine ligand (CCL) 5 from keratinocytes [17]. Desloratadine and loratadine inhibited the constitutive and IFN- $\gamma$-induced release of CCL5, C-X-C motif chemokine ligand (CXCL) 8 , and CXCL10 from keratinocytes [18]. Fexofenadine was able to inhibit the release of soluble ICAM-1 from human nasal epithelial cells and the expression of ICAM-1 in eosinophils [15].

\section{Effects on Cytokines and Proinflammatory Product Production}

Histamine is involved in the expression of IL-6 and IL-8. Combination with histamine and IL-1 can induce a higher degree of inflammation [19]. Antihistamines inhibit inflammatory cell activation through multiple mechanisms, such as the de novo generation of superoxide radicals $\left(\mathrm{O}_{2}{ }^{-}\right)$, arachidonic acid products, leukotriene
(LT) B4 and LTC4. They also attenuate the release of granule-associated products, such as neutrophil elastase and eosinophil cationic protein [14]. Antihistamines also showed inhibitory effect on cytokines such as IL-1, 4, 5, 6, 8, and 13 and IFN- $\gamma$ production from $\mathrm{T}$ cells $[15,20]$.

\section{Antiviral Activity}

Histamine promotes lytic replication via MAPK and PI3K/Akt pathway. Using samples from a cohort of human immunodeficiency virus (HIV)+ patients, the Kaposi's sarcoma-associated herpesvirus (KSHV)+ group has much higher levels of histamine in their plasma and saliva than the KSHV - group. A recent study established a high-throughput drug screening assay by using an inducible KSHV+ cell line, and proved that antihistamines displayed excellent inhibitory effects on KSHV lytic replication [21]. 


\section{Effect on Growth Hormone}

Stimulatory effect of histamine on hypothalamus-induced growth hormone $(\mathrm{GH})$ release was blocked by diphenhydramine [22]. Cyproheptadine has been shown to impair GH secretion following $\mathrm{GH}$ provocative tests [23, 24], and was used in combination with bromocriptine in patients with acromegaly [25].

\section{Effect on Sebum Production}

H-1 receptors have been identified on sebocytes. When sebocytes were incubated with an $\mathrm{H}-1$ receptor antagonist, diphenhydramine, a significant decrease in squalene levels, a biomarker for sebum, was observed [26]. H-1 antagonist may be a novel treatment option for diseases related to excess sebum production such as acne and seborrhea.

\section{Modulation on Pain and Dysesthesia}

Histamine spicules evoked sensations of itch pricking, stinging, or burning on the skin [27]. $\mathrm{H}-1$ receptor knockout mice had significantly fewer nociceptive responses to noxious stimuli [28], and H-1 antagonists, chlorpheniramine and fexofenadine, could improve the neuropathic pain signs in a mouse model [29]. Hydroxyzine is effective for relieving sensory symptoms, such as itching or dysesthesia in patients with multiple sclerosis [30].

\section{CLINICAL APPLICATIONS IN DERMATOLOGIC DISEASES}

\section{Alopecia Areata}

Histamine is thought to facilitate crosstalk with CD8 $\mathrm{T}$ cells, contributing to collapse of the follicular immune privilege observed in alopecia areata (AA) [31]. Antihistamines could downmodulate T-cell chemotaxis toward CXCL10 by reducing chemokine receptor 3 (CXCR3) expression, F-actin polymerization, and calcium influx in patients with alopecia areata [32].
Antihistamines have been used in conjunction with diphenylcyclopropenone to reduce the concomitant side effects, such as itchiness [33]. In addition, antihistamines can enhance hair regrowth. Ebastine showed remarkable hair regrowth when used together with contact immunotherapy or topical steroid for atopic AA [34]. In a retrospective cohort study, fexofenadine had a significant effect on hair regrowth in patients with atopic dermatitis and AA [35]. A recent retrospective study proved the benefit of fexofenadine and ebastine for hair regrowth when used as an adjunct to topical corticosteroid and superficial cryotherapy [36].

\section{Androgenetic Alopecia}

Prostaglandin (PG) E and PGF2a play a generally stimulatory role in hair growth, while PGD2 has an inhibitory role in hair growth [37]. Cetirizine causes a significant reduction in both the inflammatory cell infiltrate and PGD2 production [38]. Rossi et al. conducted a prospective cohort study of 85 patients to evaluate the efficacy of topical cetirizine 1\% lotion applied once a day on the scalp, in management of AGA. The results have shown that topical cetirizine $1 \%$ resulted in an increase in total hair density, terminal hair density, and diameter variation [39].

\section{Acne}

The inflammatory response of the acne is mediated by the release of histamines; thus, the introduction of antihistamines may effectively prevent the formation of new acne lesions [40]. Besides, $\mathrm{H}-1$ receptor is expressed in sebaceous glands, and a histamine- 1 receptor antagonist significantly decreases squalene levels [26].

A randomized controlled trial (RCT) including 100 patients with moderate-to-severe acne has demonstrated that the combination of isotretinoin and levocetirizine decreased the score of the Global Acne Grading System (GAGS) and acne lesion counts compared with isotretinoin alone group [41]. Another RCT showed that the combination of isotretinoin and desloratadine resulted in a more statistically significant 
decrease in acne lesion counts, the score of GAGS, and the measured value of sebum and erythema [40]. Besides, acne flare during the treatment occurred less frequently and adverse events of isotretinoin were more tolerable in the additional antihistamine group [40].

\section{Darier Disease}

Eosinophils secrete major basic protein, which disrupts desmosomes, and in turn, leads to intraepidermal bulla formation. As a result, eosinophils are hypothesized to involve the pathogenesis of vesiculobullous Darier disease. Cetirizine attenuates the migration of eosinophils and has been reported to relieve the burning sensation in a patient with vesiculobullous Darier disease [42].

\section{Eosinophilic Fasciitis}

Eosinophilia is a prominent laboratory finding in the early phase of eosinophilic fasciitis [43]. Several case reports mentioned the effect of antihistamines, such as ketotifen [44], hydroxyzine [45], and cetirizine [46] in eosinophilic fasciitis. The initiation of hydroxyzine in one 3 -year-old boy not only improved clinical symptoms but also reversed peripheral blood eosinophilia, which indicates inhibition of eosinophil migration as the mechanism of the effectiveness in eosinophilic fasciitis [45].

\section{Eosinophilic Pustular Folliculitis}

Skin biopsies of eosinophilic pustular folliculitis (EPF) find eosinophils around hair follicles. In addition to topical steroids, antihistamines such as cetirizine [47], hydroxyzine [48], and astemizole [49] have been utilized in the treatment of EPF, including several pediatric cases $[48,50]$. Inhibitory effect of antihistamines on eosinophil migration is believed to be responsible for the clinical improvement [51].

\section{Eosinophilic Cellulitis}

Additional benefit of $\mathrm{H}-1$ antihistamines when used together with oral or topical steroid has been mentioned in a systematic review [52]. Exclusive use of antihistamines had 25\% of resolution rate in eosinophilic cellulitis [53]. Cetirizine was preferred, as it inhibits eosinophil and neutrophil chemotaxis, and cetirizine alone gave a quick response and offered prolonged remission in one pediatric case [54].

\section{Erythema Gyratum Repens}

A 59-year-old man with pancreatic cancer developed erythema gyratum repens (EGR) and eosinophilia of $18.8 \%$ in peripheral blood. Biopsy of the skin lesion revealed marked spongiosis and infiltration of neutrophils and eosinophils into epidermis as well as perivascular infiltration of eosinophils, lymphocytes, and neutrophils at upper dermis. This patient responded poorly to topical steroid and oxatomide, but improved dramatically after cetirizine was administered. The antieosinophil effect of cetirizine may explain the good response in this patient [55].

\section{Erythromelalgia}

Erythromelalgia is a rare disorder characterized by burning pain of the extremities associated with red discoloration and increased temperature of the skin. The 5-HT and histamine antagonist cyproheptadine and pizotifen effectively relieved the burning pain and increased skin temperature $[56,57]$. A survey of the members of The Erythromelalgia Association reported marked improvement in $40 \%$ of patients with antihistamines, including desloratadine, chlorpheniramine, and diphenhydramine [58]. A child with erythromelalgia responded to cetirizine, and his symptoms aggravated once cetirizine was discontinued [59]. Antihistamines have potent vascular effects and reduce or abolish the augmentation in local circulation elicited by histamine, which may explain its effect on erythromelalgia [60]. 


\section{Hypereosinophilic Syndrome}

Hypereosinophilic syndrome is a multisystem disease with a significant mortality rate. It is characterized by peripheral blood eosinophilia and infiltration of eosinophils into many organs, including skin [61]. A 66-year-old patient presented with swelling and pruritic erythematous eruptions on his legs. Peripheral blood sampling showed 53\% eosinophils (4876/ $\mu \mathrm{L})$. Bilastine $20 \mathrm{mg}$ daily was initiated, and the eruption improved and peripheral blood eosinophil reverted [62]. Bilastine is highly selective for $\mathrm{H}-1$ receptor binding. Its inhibitory effect on eosinophil chemotaxis may explain the effect on reversal of hypereosinophilia [63].

\section{Kaposi Sarcoma}

Mast cells (MC) are identified as proinflammatory cells within Kaposi sarcoma (KS) lesions. In addition to their inhibitory role on MC activation, antihistamines may suppress KSHV lytic replication via inhibition of MAPK and PI3K/ Akt pathway [21]. A patient with acquired immunodeficiency syndrome (AIDS)-KS with extensive mast-cell infiltration on biopsy experienced durable and rapid regression after the initiation of cetirizine, ranitidine, and montelukast, which indicated that antihistamines may be a novel therapeutic approach in KS [64].

\section{Lichen Nitidus}

Lichen nitidus presents with tiny, monomorphous, lichenoid, mostly asymptomatic papules in regional or disseminated distribution that shows a pathognomonic histological pattern [65]. H-1 antihistamines such as astemizole $[66,67]$ and cyproheptadine [68] have been reported to be beneficial in case reports of patients with generalized lichen nitidus. However, the propensity for the disease to resolve spontaneously makes it difficult to evaluate the true effectiveness of various therapies for this disease [69].

\section{Lichen Planopilaris}

In a prospective cohort study including 21 patients with lichen planopilaris (LPP), the combination of topical steroid and cetirizine achieved targeted treatment response in 17 patients, and was noninferior to the combination of topical steroid and other systemic therapies. In some patients with contemporaneous cutaneous lichen planus, the lesions cleared without any topical treatment, indicating that cetirizine itself may be beneficial [70]. In a retrospective study investigating the demographic and clinical profiles of 103 Chilean adults with LPP, the authors concluded that treatment protocol of LPP commonly required sustained combination of at least one topical and one systemic agent in a stepwise manner. Clobetasol shampoo or lotion with oral cetirizine appeared to be a first-line treatment option for Chilean physicians since they were used in all included patients [71]. Cetirizine reduces the number of tryptase-positive mast cells that are possibly involved in the pathogenesis of LPP [72].

\section{Malignant Acanthosis Nigricans}

Malignant acanthosis nigricans (MAN) is usually regarded unresponsive to treatment other than that aimed at clearing the underlying neoplasm. There is a case report of MAN regressing rapidly following treatment with cyproheptadine despite progression of metastatic disease. It is postulated that flattening of MAN following administration of cyproheptadine was due to the reduction of growth hormone release either from the pituitary or from the tumor or metastases [73].

\section{Melanoma}

Chronic inflammation induces both proliferation of resident mast cells and recruitment of mast cells and their precursors, which have been associated with angiogenesis, tumor growth, and metastasis. Mast cell density was described as an indicator of poor prognosis in melanoma [74]. In vitro studies with human cell lines of melanoma showed positive 
involvement of histamine in cancer cell proliferation, migration, and invasion [75]. Diphenhydramine induces melanoma cell apoptosis and retards melanoma growth in a mouse model [76].

A retrospective cohort study analyzed 1253 individuals diagnosed with primary cutaneous malignant melanoma and received $\mathrm{H} 1$-antihistamines, including desloratadine, cetirizine, loratadine, clemastine, ebastine, and fexofenadine. Desloratadine and loratadine are associated with improved survival and have a potential role in melanoma treatment [77].

\section{Psoriasis}

Psoriasis is characterized by the cutaneous expression of adhesion molecules such as ICAM-1, ICAM-3, and lymphocyte function-associated antigen (LFA)-1 [78]. Cetirizine has been proven to reduce the expression of ICAM1, ICAM-3, and LFA-1 on keratinocytes and, subsequently, the migration of inflammatory cells in psoriatic skin lesions [78, 79]. Besides, release of histamine from mast cells in psoriatic plaque is important for maintenance of the disease [80]. Cetirizine significantly reduced the expression of tryptase-positive mast cells and produced a clinical improvement in erythema, thickness, and scaling in a prospective cohort study [80].

\section{Radiation Dermatitis}

An animal study suggests that gamma irradiation-induced erythema and edema were caused by histamine released from mast cells via histamine $\mathrm{H} 1$ receptor. Besides, bepotastine significantly reduced the extent of dry desquamation and epilation in a mouse model [81]. Antihistamines such as azelastine could improve the skin tolerance without affecting the antitumor effects [82]. A retrospective cohort study showed that administration of azelastine reduced the incidence of moist desquamation in radiation dermatitis [83].

\section{Scalp Dysesthesia}

Oral pregabalin, gabapentin, and topical analgesic agents were considered first-line medications for scalp dysesthesia. Corticosteroid lotions and oral antihistamines did not work on their own but brought additive value when they were used with analgesic agents [84]. In a case series of 11 patients, one responded completely to treatment of sertraline and hydroxyzine [85]. Cutaneous dysesthesia, itch, and nociceptive sensation could be evoked by spicules of capsaicin and histamine [86], which may explain why antihistamines have additional benefits for scalp dysesthesia.

\section{DISCUSSION}

In this review, we summarize the wide-ranging usages of H-1 antihistamines in dermatological fields other than itch and urticaria control. A synopsis of included studies and evidence level based on Oxford Centre for EBM (OCEBM) are presented in Table 1 [87]. Modulation of immune system, inflammatory cytokines, and mast cells explains why $\mathrm{H}-1$ antihistamines are effective in some autoimmune disorders and malignancies, such as alopecia areata, Kaposi sarcoma, and melanoma. Some H-1 antihistamines, for example, cetirizine and bilastine, affects eosinophil chemotaxis and has been proven to be beneficial in certain eosinophilic dermatoses. Other H-1 antihistamines, such as hydroxyzine, together with GABA receptor agonist have extra effect on cutaneous dysesthesia. Combination of antihistamines with isotretinoin provides better acne control possibly due to inhibition of sebum production. Lastly, reversing the vascular effect of histamine appears useful for erythema, edema, and pain control in radiation dermatitis and erythromelalgia. Novel properties of antihistamines have been investigated, including antibacterial activity [2, 3], antiangiogenesis [5-7], and antifibrosis [8, 9] effects observed in studies in vitro, but proven dermatological applications are lacking.

When interpreting the result of this review, one must be cautious of the following 
Table 1 Studies and case reports on the use of H-1 antihistamines for dermatologic disorders

\begin{tabular}{|c|c|c|c|c|c|c|}
\hline Disease & Drug and dosage & $\begin{array}{l}\text { Response to } \\
\text { treatment }\end{array}$ & $\begin{array}{l}\text { Proposed } \\
\text { mechanism }\end{array}$ & Type of study & $\begin{array}{l}\text { Level of } \\
\text { evidence } \\
\text { (OCEBM) }\end{array}$ & References \\
\hline Alopecia areata & $\begin{array}{l}\text { Fexofenadine }(180 \mathrm{mg} / \text { day }) \text { or } \\
\text { ebastine }(10 \mathrm{mg} / \text { day }) \text { in } \\
\text { combination with contact } \\
\text { immunotherapy, superficial } \\
\text { cryotherapy, or topical } \\
\text { corticosteroid }\end{array}$ & $\begin{array}{l}\text { Accelerated hair } \\
\text { regrowth }\end{array}$ & $\begin{array}{l}\text { Downmodulation } \\
\text { of T-cell } \\
\text { chemotaxis } \\
\text { Modulation of } \\
\text { expression of } \\
\text { adhesion } \\
\text { molecules on } \\
\text { keratinocytes }\end{array}$ & $\begin{array}{l}\text { Retrospective cohort } \\
\text { studies }(n=121, \\
n=148), \\
\text { prospective cohort } \\
\text { study }(n=13) \text {, and } \\
\text { case reports }\end{array}$ & 3 & {$[33-35]$} \\
\hline $\begin{array}{l}\text { Androgenetic } \\
\text { alopecia }\end{array}$ & Topical $1 \%$ cetirizine & $\begin{array}{l}\text { Increase in total } \\
\text { hair density and } \\
\text { terminal hair } \\
\text { density }\end{array}$ & $\begin{array}{l}\text { Decreased PGD2 } \\
\text { production } \\
\text { Antiinflammatory } \\
\text { effect }\end{array}$ & $\begin{array}{l}\text { Prospective cohort } \\
\text { study }(n=85)\end{array}$ & 3 & {$[39]$} \\
\hline Acne & $\begin{array}{l}\text { Levocetirizine }(5 \mathrm{mg} / \text { day }) \text { or } \\
\text { desloratadine }(5 \mathrm{mg} / \text { day }) \text { in } \\
\text { combination with isotretinoin }\end{array}$ & $\begin{array}{l}\text { Decrease in acne } \\
\text { lesion counts and } \\
\text { global acne } \\
\text { grading system }\end{array}$ & $\begin{array}{l}\text { Decreased sebum } \\
\text { production }\end{array}$ & $\begin{array}{l}\text { Randomized } \\
\text { controlled trials } \\
\quad(n=40, n=50)\end{array}$ & 2 & {$[40,41]$} \\
\hline Darier disease & Cetirizine $(10-40 \mathrm{mg} /$ day $)$ & $\begin{array}{l}\text { Improvement of } \\
\text { burning } \\
\text { sensation }\end{array}$ & $\begin{array}{c}\text { Inhibition of } \\
\text { eosinophil } \\
\text { migration }\end{array}$ & Case report & 4 & {$[42]$} \\
\hline $\begin{array}{l}\text { Eosinophilic } \\
\text { fasciitis }\end{array}$ & $\begin{array}{l}\text { Hydroxyzine }(2 \mathrm{mg} / \mathrm{kg} / \mathrm{day}) \text {, } \\
\text { ketotifen or cetirizine } \\
(10 \mathrm{mg} / \text { day })\end{array}$ & $\begin{array}{l}\text { Reversal of } \\
\text { eosinophilia and } \\
\text { clinical } \\
\text { symptoms }\end{array}$ & $\begin{array}{l}\text { Inhibition of } \\
\text { eosinophil } \\
\text { migration }\end{array}$ & Case reports & 4 & {$[44-46]$} \\
\hline $\begin{array}{l}\text { Eosinophilic } \\
\text { pustular } \\
\text { folliculitis }\end{array}$ & $\begin{array}{l}\text { Cetirizine }(20-40 \mathrm{mg} / \text { day }), \\
\text { hydroxyzine or astemizole } \\
(10-20 \mathrm{mg} / \text { day })\end{array}$ & $\begin{array}{l}\text { Reduction in } \\
\text { symptoms and } \\
\text { number of } \\
\text { lesions }\end{array}$ & $\begin{array}{l}\text { Inhibition of } \\
\text { eosinophil } \\
\text { migration }\end{array}$ & $\begin{array}{l}\text { Case reports and case } \\
\text { series }(n=13)\end{array}$ & 4 & {$[47-50]$} \\
\hline $\begin{array}{c}\text { Eosinophilic } \\
\text { cellulitis }\end{array}$ & $\begin{array}{l}\text { Cetirizine }(30-40 \mathrm{mg} / \text { day }) \text { in } \\
\text { combination with oral steroid }\end{array}$ & Complete recovery & $\begin{array}{l}\text { Inhibition of } \\
\text { eosinophil and } \\
\text { neutrophil } \\
\text { migration }\end{array}$ & $\begin{array}{l}\text { Case reports and case } \\
\text { series }(n=2)\end{array}$ & 4 & {$[52,53]$} \\
\hline $\begin{array}{l}\text { Erythema gyratum } \\
\text { repens }\end{array}$ & Cetirizine $(10 \mathrm{mg} /$ day $)$ & $\begin{array}{l}\text { Reversal of } \\
\text { eosinophilia, } \\
\text { clinical } \\
\text { symptoms, and } \\
\text { skin lesions }\end{array}$ & $\begin{array}{c}\text { Inhibition of } \\
\text { eosinophil } \\
\text { migration }\end{array}$ & Case report & 4 & {$[55]$} \\
\hline Erythromelalgia & $\begin{array}{l}\text { Cyproheptadine }(12-24 \mathrm{mg} / \text { day }) \text {, } \\
\text { pizotifen, desloratadine, } \\
\text { chlorpheniramine, } \\
\text { diphenhydramine, or cetirizine }\end{array}$ & $\begin{array}{l}\text { Relief of pain and } \\
\text { burning } \\
\text { sensation }\end{array}$ & $\begin{array}{l}\text { Reduction or } \\
\text { elimination of } \\
\text { the } \\
\text { augmentation } \\
\text { in local } \\
\text { circulation }\end{array}$ & Case reports & 4 & {$[56-59]$} \\
\hline $\begin{array}{l}\text { Hypereosinophilic } \\
\text { syndrome }\end{array}$ & Bilastine (20 mg/day) & $\begin{array}{l}\text { Reversal of } \\
\text { eosinophilia, } \\
\text { clinical } \\
\text { symptoms, and } \\
\text { skin lesions }\end{array}$ & $\begin{array}{c}\text { Inhibition of } \\
\text { eosinophil } \\
\text { migration }\end{array}$ & Case reports & 4 & {$[62]$} \\
\hline
\end{tabular}


Table 1 continued

\begin{tabular}{|c|c|c|c|c|c|c|}
\hline Disease & Drug and dosage & $\begin{array}{l}\text { Response to } \\
\text { treatment }\end{array}$ & $\begin{array}{l}\text { Proposed } \\
\text { mechanism }\end{array}$ & Type of study & $\begin{array}{l}\text { Level of } \\
\text { evidence } \\
\text { (OCEBM) }\end{array}$ & References \\
\hline Kaposi sarcoma & $\begin{array}{l}\text { Cetirizine }(20 \mathrm{mg} / \text { day }) \text { with } \\
\text { ranitidine or montelukast }\end{array}$ & $\begin{array}{l}\text { Durable and rapid } \\
\text { regression of } \\
\text { tumors }\end{array}$ & $\begin{array}{l}\text { Inhibition of } \\
\text { mast-cell } \\
\text { activation } \\
\text { Inhibition of } \\
\text { KSHV lytic } \\
\text { replication }\end{array}$ & Case report & 4 & {$[64]$} \\
\hline Lichen nitidus & $\begin{array}{l}\text { Astemizole }(10 \mathrm{mg} / \text { day }) \text { or } \\
\text { cyproheptadine in combination } \\
\text { with topical steroid }\end{array}$ & $\begin{array}{l}\text { Remission of skin } \\
\text { lesions }\end{array}$ & Unclear & $\begin{array}{l}\text { Case reports and case } \\
\text { series }(n=2)\end{array}$ & 4 & {$[66-69]$} \\
\hline Lichen planopilaris & $\begin{array}{l}\text { Cetirizine }(5-30 \mathrm{mg} / \text { day }) \text { in } \\
\text { combination with topical } \\
\text { steroid }\end{array}$ & $\begin{array}{l}\text { Cessation of the } \\
\text { inflammation } \\
\text { (erythema, } \\
\text { follicular } \\
\text { hyperkeratosis, } \\
\text { loss of anagen } \\
\text { hair) }\end{array}$ & $\begin{array}{l}\text { Reduction in } \\
\text { number of mast } \\
\text { cells and } \\
\text { inhibition of } \\
\text { mast-cell } \\
\text { activation }\end{array}$ & $\begin{array}{l}\text { Prospective cohort } \\
\text { study }(n=21)\end{array}$ & 3 & {$[70]$} \\
\hline $\begin{array}{l}\text { Malignant } \\
\text { acanthosis } \\
\text { nigricans }\end{array}$ & Cyproheptadine (12 mg/day) & $\begin{array}{l}\text { Remission of skin } \\
\text { lesions }\end{array}$ & $\begin{array}{l}\text { Reduction of } \\
\text { growth } \\
\text { hormone release }\end{array}$ & Case report & 4 & {$[73]$} \\
\hline Melanoma & Desloratadine and loratadine & $\begin{array}{l}\text { Improved } \\
\text { melanoma } \\
\text { survival }\end{array}$ & $\begin{array}{l}\text { Inhibition of } \\
\text { mast-cell } \\
\text { activation } \\
\text { Antiinflammatory } \\
\text { effect }\end{array}$ & $\begin{array}{c}\text { Retrospective cohort } \\
\text { study }(n=1253)\end{array}$ & 3 & {$[77]$} \\
\hline Psoriasis & Cetirizine $(30 \mathrm{mg} /$ day $)$ & $\begin{array}{l}\text { Improved lesion } \\
\text { thickness, } \\
\text { erythema, and } \\
\text { scaling }\end{array}$ & $\begin{array}{l}\text { Modulation of } \\
\text { expression of } \\
\text { adhesion } \\
\text { molecules on } \\
\text { keratinocytes } \\
\text { Reduction in } \\
\text { number of mast } \\
\text { cells }\end{array}$ & $\begin{array}{l}\text { Prospective cohort } \\
\text { study }(n=10)\end{array}$ & 3 & {$[80]$} \\
\hline $\begin{array}{l}\text { Radiation } \\
\text { dermatitis }\end{array}$ & $\begin{array}{c}\text { Azelastine }(1.3 \mathrm{mg} / \mathrm{kg} / \mathrm{day}) \text { and } \\
\text { bepotastine }(10 \mathrm{mg} / \mathrm{kg} / \text { day })\end{array}$ & $\begin{array}{l}\text { Mouse model } \\
\text { Reduction of } \\
\text { erythema, } \\
\text { desquamation, } \\
\text { and edema }\end{array}$ & $\begin{array}{l}\text { Reduction or } \\
\text { elimination of } \\
\text { the } \\
\text { augmentation } \\
\text { in local } \\
\text { circulation }\end{array}$ & $\begin{array}{l}\text { Retrospective cohort } \\
\text { study }(n=48)\end{array}$ & 3 & {$[83]$} \\
\hline Scalp dysesthesia & $\begin{array}{l}\text { Unspecified antihistamines in } \\
\text { combination with analgesic } \\
\text { agents }\end{array}$ & $\begin{array}{l}\text { Relief of pain and } \\
\text { burning } \\
\text { sensation }\end{array}$ & $\begin{array}{l}\text { Reversal of } \\
\text { histamine- } \\
\text { induced } \\
\text { dysesthesia, itch, } \\
\text { and nociceptive } \\
\text { sensation }\end{array}$ & $\begin{array}{l}\text { Case series }(n=4 \\
n=11)\end{array}$ & 4 & {$[84,85]$} \\
\hline
\end{tabular}

OCEBM Oxford Centre for Evidence-Based Medicine, https://www.cebm.ox.ac.uk/resources/levels-of-evidence/ocebm-levels-of-evidence, PGD2 prostaglandin D2, KSHV Kaposi's sarcoma-associated herpesvirus 
limitations. The evidence supporting off-label use of $\mathrm{H}-1$ antihistamines is relatively weak, with only two RCTs showing a beneficial effect in combination with isotretinoin for the treatment of acne [40, 41]. In other diseases, the response of antihistamines was only described in case reports, case series, and prospective or retrospective cohort studies; thus, RCTs are warranted to better evaluate their true efficacy. Besides, in many case reports, the effect of antihistamines was derived from clinical subjective judgment, which may misinterpret the real curative agent if the patient is under multiple medications. Lastly, many diseases that responded to antihistamines are never reported in the literature, and we may have missed some reports by limiting our searches to articles in PubMed or Embase. Nonetheless, with more and more properties of $\mathrm{H}-1$ antihistamines unveiled, they could be considered as a safe, economic, and promising tool that may alter the disease course and pathogenesis of various dermatological disorders.

\section{CONCLUSION}

Pleiotropic effects of $\mathrm{H}-1$ antagonists have been discovered. RCT has proven their additional benefit for acne when used in combination with oral isotretinoin. Prospective studies indicated that they may be helpful in alopecia areata, androgenetic alopecia, lichen planopilaris, and psoriasis. Large retrospective studies also showed promising results for the treatment of alopecia areata, melanoma, and radiation dermatitis. Use for other dermatological diseases, such as Darier disease, eosinophilic dermatoses, paraneoplastic dermatoses, lichen nitidus, and skin dysesthesia, has been documented only in anecdotal case reports. Whether an uptitration of $\mathrm{H}-1$ antihistamine will provide additional benefits, as shown in chronic urticaria in the aforementioned diseases in this manuscript, needs to be further verified. Although the evidence supporting the use of $\mathrm{H}-1$ antihistamines for dermatologic purposes other than itch and urticaria control remains limited, more studies are encouraged, considering the relative low cost and safety of H-1 antihistamine.

\section{ACKNOWLEDGEMENTS}

Funding. No funding or sponsorship was received for the study or publication of this article.

Authorship. All named authors meet the International Committee of Medical Journal Editors (ICMJE) criteria for authorship for this article, take responsibility for the integrity of the work as a whole, and have given their approval for this version to be published.

Author Contributions. Dr. C-YH conducted the literature search, summarized the identified papers and drafted the manuscript. Dr. T-FT is responsible for the ideation of this topic and final refinement of this article.

Prior Presentation. This manuscript is based on work previously presented as a poster at European Respiratory Society (ERS) International Congress, 28 September-02 October 2019, Madrid, Spain.

Disclosures. Tsen-Fang Tsai has conducted clinical trials or received honoraria for serving as a consultant for Abbvie, Boehringer Ingelheim, Bristol-Myers Squibb, Celgene, Eli-Lilly, Galderma, Janssen-Cilag, Merck Sharp \& Dohme, Novartis International AG, Pfizer Inc., and UCB Pharma and is Editorial board member of the journal. Chang-Yu Hsieh has nothing to disclose.

Compliance with Ethics Guidelines. This article is based on previously conducted studies and does not contain any studies with human participants or animals performed by any of the authors.

Data Availability. Data sharing is not applicable to this article as no datasets were generated or analyzed during the current study. This article is based on previously conducted studies. Searching strategies were specified in "Method of Literature Search". 
Open Access. This article is licensed under a Creative Commons Attribution-NonCommercial 4.0 International License, which permits any non-commercial use, sharing, adaptation, distribution and reproduction in any medium or format, as long as you give appropriate credit to the original author(s) and the source, provide a link to the Creative Commons licence, and indicate if changes were made. The images or other third party material in this article are included in the article's Creative Commons licence, unless indicated otherwise in a credit line to the material. If material is not included in the article's Creative Commons licence and your intended use is not permitted by statutory regulation or exceeds the permitted use, you will need to obtain permission directly from the copyright holder. To view a copy of this licence, visit http://creativecommons.org/licenses/by$\mathrm{nc} / 4.0 /$.

\section{REFERENCES}

1. Albrecht M, Dittrich AM. Expression and function of histamine and its receptors in atopic dermatitis. Mol Cell Pediatr. 2015;2:1-8. https://doi.org/10. 1186/s40348-015-0027-1.

2. El-Nakeeb MA, Abou-Shleib HM, Khalil AM, Omar HG, El-Halfawy OM. In vitro antibacterial activity of some antihistaminics belonging to different groups against multi-drug resistant clinical isolates. Braz J Microbiol. 2011;42:980-91.

3. Lagadinou M, Onisor MO, Rigas A, Musetescu DV, Gkentzi D, Assimakopoulos SF, et al. Antimicrobial properties on non-antibiotic drugs in the era of increased bacterial resistance. Antibiotics. 2020;9: $1-12$.

4. Chopra S, Matsuyama K, Hutson C, Madrid P. Identification of antimicrobial activity among FDAapproved drugs for combating Mycobacterium abscessus and Mycobacterium chelonae. J Antimicrob Chemother. 2011;66:1533-6.

5. Xia Q, Yang S, Zhang SQ, Chen B, Wang DB, Zhu $\mathrm{QX}$, et al. The effect of mizolastine on expression of vascular endothelial cell growth factor, tumour necrosis factor- $\alpha$ and keratinocyte-derived chemokine in murine mast cells, compared with dexamethasone and loratadine. Clin Exp Dermatol. 2005;30:165-70.
6. Russo A, Russo G, Peticca M, Pietropaolo C, Di Rosa $M$, Iuvone $T$. Inhibition of granuloma-associated angiogenesis by controlling mast cell mediator release: role of mast cell protease-5. Br J Pharmacol. 2005;145:24-33.

7. Ionov ID, Gorev NP, Roslavtseva LA, Frenkel DD. Cetirizine and thalidomide synergistically inhibit mammary tumorigenesis and angiogenesis in 7,12dimethylbenz(a) anthracene-treated rats. Anticancer Drugs. 2018;29:956-64.

8. Wolak M, Bojanowska E, Staszewska T, Ciosek J, Juszczak M, Drobnik J. The role of histamine in the regulation of the viability, proliferation and transforming growth factor $\beta 1$ secretion of rat wound fibroblasts. Pharmacol Rep. 2017;69:314-21. https://doi.org/10.1016/j.pharep.2016.11.006.

9. Murota H, Bae S, Hamasaki Y, Maruyama R, Katayama I. Emedastine difumarate inhibits histamine-induced collagen synthesis in dermal fibroblasts. J Investig Allergol Clin Immunol. 2008;18:245-52.

10. Topol BM, Lewis VLJ, Benveniste K. The use of antihistamine to retard the growth of fibroblasts derived from human skin, scar, and keloid. Plast Reconstr Surg. 1981;68:227-32.

11. Suzawa H, Kikuchi S, Arai N, Koda A. The mechanism involved in the inhibitory action of tranilast on collagen biosynthesis of keloid fibroblasts. Jpn J Pharmacol. 1992;60:91-6.

12. Penicheid AG, Osorio EY, Melby PC, Travi BL. Efficacy of histamine $\mathrm{H} 1$ receptor antagonists azelastine and fexofenadine against cutaneous leishmania major infection. PLoS Negl Trop Dis. 2020;14:1-17. https://doi.org/10.1371/journal. pntd.0008482.

13. de Melo Mendes V, Tempone AG, Treiger Borborema SE. Antileishmanial activity of H1-antihistamine drugs and cellular alterations in Leishmania (L.) infantum. Acta Trop. 2019;195:6-14. https:// doi.org/10.1016/j.actatropica.2019.04.017.

14. Church MK. Non-H1-receptor effects of antihistamines. Clin Exp Allergy. 1999;29:39-48.

15. Vena G, Cassano N, Buquicchio R, Ventura M. Antiinflammatory effects of H1-antihistamines: clinical and immunological relevance. Curr Pharm Des. 2008;14:2902-11.

16. Bäumer W, Roßbach K. Histamin als Immunmodulator. J Ger Soc Dermatol. 2010;8:495-504.

17. Albanesi C, Pastore S, Fanales-Belasio E, Girolomoni G. Cetirizine and hydrocortisone differentially regulate ICAM-1 expression and chemokine release in 
cultured human keratinocytes. Clin Exp Allergy. 1998;28:101-9.

18. Traidl-Hoffmann C, Münster I, Ring J, Behrendt H. Impact of desloratadine and loratadine on the crosstalk between human keratinocytes and leukocytes: implications for anti-inflammatory activity of antihistamines. Int Arch Allergy Immunol. 2006;140:315-20.

19. Conti P, Caraffa A, Tetè G, Gallenga CE, Ross R, Kritas SK, et al. Mast cells activated by SARS-CoV-2 release histamine which increases IL-1 levels causing cytokine storm and inflammatory reaction in COVID-19. J Biol Regul Homeost Agents Italy. 2020;34:1629-32.

20. Walsh GM. Anti-inflammatory properties of antihistamines: an update. Clin Exp Allergy Rev. 2005;5:21-5.

21. Chen J, Dai L, Goldstein A, Zhang H, Tang W, Craig Forrest J, et al. Identification of new antiviral agents against Kaposi's sarcoma-associated herpesvirus (KSHV) by high-throughput drug screening reveals the role of histamine-related signaling in promoting viral lytic reactivation. PLoS Pathog. 2019;15: $1-25$.

22. Hall TR, Harvey S, Chadwick A. Prolactin and growth hormone secretion in chickens: stimulation by histamine and inhibition by gamma-aminobutyric acid. Acta Endocrinol. 1984;107:36-41.

23. Mahachoklertwattana $\mathrm{P}$, Wanasuwankul S, Poomthavorn P, Choubtum L, Sriphrapradang A. Short-term cyproheptadine therapy in underweight children: effects on growth and serum insulin-like growth factor-I. J Pediatr Endocrinol Metab. 2009;22:425-32.

24. Rosskamp RH, Haverkamp F, von Kalckreuth G. The effect of cyproheptadine on plasma growth hormone $(\mathrm{GH})$ and on somatostatin response to GHreleasing hormone in man. Horm Metab Res. 1990;22:295-7.

25. Hanew K, Sugawara A, Shimizu Y, Sato S, Sasaki A, Tazawa S, et al. The combination therapy with bromocriptine and cyproheptadine in patients with acromegaly. Endocrinol Jpn. 1989;36:429-38.

26. Pelle E, McCarthy J, Seltmann H, Huang X, Mammone $\mathrm{T}$, Zouboulis CC, et al. Identification of histamine receptors and reduction of squalene levels by an antihistamine in sebocytes. J Invest Dermatol. 2008;128:1280-5.

27. Sikand P, Shimada SG, Green BG, LaMotte RH. Similar itch and nociceptive sensations evoked by punctate cutaneous application of capsaicin, histamine and cowhage. Pain. 2009;144:66-75. https://doi.org/10.1016/j.pain.2009.03.001.

28. Mobarakeh JI, Sakurada S, Katsuyama S, Kutsuwa M, Kuramasu A, Lin ZY, et al. Role of histamine H1 receptor in pain perception: a study of the receptor gene knockout mice. Eur J Pharmacol. 2000;391: 81-9.

29. Khalilzadeh E, Azarpey F, Hazrati R, Vafaei SG. Evaluation of different classes of histamine $\mathrm{H} 1$ and $\mathrm{H} 2$ receptor antagonist effects on neuropathic nociceptive behavior following tibial nerve transection in rats. Eur J Pharmacol. 2018;834:221-9. https://doi.org/10.1016/j.ejphar.2018.07.011.

30. Logothetis L, Mylonas IA, Baloyannis S, Pashalidou M, Orologas A, Zafeiropoulos A, et al. A pilot, open label, clinical trial using hydroxyzine in multiple sclerosis. Int J Immunopathol Pharmacol. 2005;18: 771-8.

31. Bertolini M, Zilio F, Rossi A, Kleditzsch P, Emelianov VE, Gilhar A, et al. Abnormal interactions between perifollicular mast cells and CD8+ T-cells may contribute to the pathogenesis of alopecia areata. PLoS ONE. 2014;9:e94260. https://doi.org/ 10.1371/journal.pone.0094260.

32. Ito T, Fujiyama T, Hashizume H, Tokura Y. Antihistaminic drug olopatadine downmodulates $\mathrm{T}$ cell chemotaxis toward CXCL10 by reducing CXCR3 expression, F-actin polymerization and calcium influx in patients with alopecia areata. J Dermatol Sci. 2013;72:68-71.

33. Katagiri K, Arakawa S, Hatano Y, Fujiwara S. Fexofenadine, an H1-receptor antagonist, partially but rapidly inhibits the itch of contact dermatitis induced by diphenylcyclopropenone in patients with alopecia areata. J Dermatol. 2006;33:75-9.

34. Ohyama M, Shimizu A, Tanaka K, Amagai M. Experimental evaluation of ebastine, a secondgeneration anti-histamine, as a supportive medication for alopecia areata. J Dermatol Sci. 2010;58: 154-7. https://doi.org/10.1016/j.jdermsci.2010.03. 009.

35. Inui $\mathrm{S}$, Nakajima $\mathrm{T}$, Toda $\mathrm{N}$, Itami S. Fexofenadine hydrochloride enhances the efficacy of contact immunotherapy for extensive alopecia areata: retrospective analysis of 121 cases. J Dermatol. 2009;36:323-7.

36. Lee YB, Lee W-S. Efficacy of antihistamines in combination with topical corticosteroid and superficial cryotherapy for treatment of alopecia areata: a retrospective cohort study. J Am Acad Dermatol. 2020. https://doi.org/10.1016/j.jaad. 2020.06.1026. 
37. Garza LA, Liu Y, Yang Z, Alagesan B, Lawson JA, Norberg SM, et al. Prostaglandin D2 inhibits hair growth and is elevated in bald scalp of men with androgenetic alopecia. Sci Transl Med. 2012;4: 126-34.

38. Charlesworth EN, Kagey-Sobotka A, Norman PS, Lichtenstein LM. Effect of cetirizine on mast cellmediator release and cellular traffic during the cutaneous late-phase reaction. J Allergy Clin Immunol. 1989;83:905-12.

39. Rossi A, Campo D, Fortuna MC, Garelli V, Pranteda G, De Vita G, et al. A preliminary study on topical cetirizine in the therapeutic management of androgenetic alopecia. J Dermatolog Treat. 2018;29:149-51. 09546634.2017 .1341610 .

40. Lee HE, Chang IK, Lee Y, Kim CD, Seo YJ, Lee JH, et al. Effect of antihistamine as an adjuvant treatment of isotretinoin in acne: a randomized, controlled comparative study. J Eur Acad Dermatol Venereol. 2014;28:1654-60.

41. Pandey D, Agrawal S. Efficacy of isotretinoin and antihistamine versus isotretinoin alone in the treatment of moderate to severe acne: a randomised control trial. Kathmandu Univ Med J. 2019;17: 14-9.

42. Wang JF, Lederhandler MH, Brinster N, Soter NA, $\mathrm{Ba}$ JFW, Lederhandler $\mathrm{MH}$, et al. Vesiculobullous Darier disease symptomatically responsive to cetirizine. J Drugs Dermatol. 2019;18:213-4.

43. Falanga V, Medsger TAJ. Frequency, levels, and significance of blood eosinophilia in systemic sclerosis, localized scleroderma, and eosinophilic fasciitis. J Am Acad Dermatol. 1987;17:648-56.

44. Ching DW, Leibowitz MR. Ketotifen-a therapeutic agent of eosinophilic fasciitis? J Intern Med. 1992;231:555-9.

45. Uçkun A, Sipahi T, Akgün D, Oksal A. Eosinophilic fasciitis successfully treated with oral hydroxyzine: a new therapeutic use of an old drug? Eur J Pediatr. 2002;161:118-9.

46. HurJW, Lee HS, Uhm WS, Jun JB, Bae SC, Park CK, et al. Eosinophilic fasciitis associated with autoimmune thyroiditis. Korean J Intern Med. 2005;20:180-2.

47. Harris DWS, Ostelere L, Buckley C, Johnson M, Rustin MHA. Eosinophilic pustular folliculitis in an HIV-positive man: response to cetirizine. Br J Dermatol. 1992;126:392-4.

48. Luelmo Aguilar J, Sáez AA. Eosinophilic pustular folliculitis in childhood. An Esp Pediatr. 2001;55: 154-8.
49. Rosenthal D, LeBoit PE, Klumpp L, Berger TG. Human immunodeficiency virus-associated eosinophilic folliculitis. A unique dermatosis associated with advanced human immunodeficiency virus infection. Arch Dermatol. 1991;127:206-9.

50. Odyakmaz Demirsoy E, Demirsoy U, Ozod U, Kiran R. Eosinophilic pustular folliculitis of infancy suppressed with cetirizine. Pediatr Dermatol. 2019;36: 395-6.

51. Ellis E, Scheinfeld N. Eosinophilic pustular folliculitis: a comprehensive review of treatment options. Am J Clin Dermatol. 2004;5:189-97.

52. Räßler F, Lukács J, Elsner P. Treatment of eosinophilic cellulitis (Wells syndrome) - a systematic review. J Eur Acad Dermatol Venereol. 2016;30: 1465-79.

53. Sinno H, Lacroix JP, Lee J, Izadpanah A, Borsuk R, Watters $\mathrm{K}$, et al. Diagnosis and management of eosinophilic cellulitis (Wells' syndrome): a case series and literature review. Can J Plast Surg. 2012;20:91-7.

54. Aroni K, Aivaliotis M, Liossi A, Davaris P. Eosinophilic cellulitis in a child successfully treated with cetirizine. Acta Derm Venereol. 1999;79:332.

55. Miyagawa F, Danno K, Uehara M. Erythema gyratum repens responding to cetirizine hydrochloride. J Dermatol. 2002;29:731-4. https://doi.org/10. 1111/j.1346-8138.2002.tb00211.x.

56. Guillet $\mathrm{MH}$, Le Noach E, Milochau P, Sassolas B, Guillet G. Familial erythermalgia treated with pizotifen. Ann Dermatol Venereol. 1995;122:777-9.

57. Sakakibara R, Fukutake T, Kita K, Hattori T. Treatment of primary erythromelalgia with cyproheptadine. J Auton Nerv Syst. 1996;58:121-2.

58. Tham SW, Giles M. Current pain management strategies for patients with erythromelalgia: a critical review. J Pain Res. 2018;11:1689-98.

59. Al-Minshawy SM, El-Mazary AAM. An Egyptian child with erythromelalgia responding to a new line of treatment: a case report and review of the literature. J Med Case Rep. 2014;8:1-6.

60. Abramson D, Tuck S, Chu LDT. Vascular effects of chlorpheniramine maleate. J Allergy. 1963;34: 258-69.

61. Yoon TY, Ahn GB, Chang SH. Complete remission of hypereosinophilic syndrome after interferon- $\alpha$ therapy: report of a case and literature review. J Dermatol. 2000;27:110-5. 
62. Sugita K, Yamamoto O. Hypereosinophilia successfully treated with the novel antihistamine bilastine. Clin Exp Dermatol. 2019;44:586-8.

63. Corcóstegui R, Labeaga L, Innerárity A, Berisa A, Orjales A. In vivo pharmacological characterisation of bilastine, a potent and selective histamine $\mathrm{H} 1$ receptor antagonist. Drugs R\&D. 2006;7:219-31.

64. Ayers LW, Barbachano-Guerrero A, McAllister SC, Ritchie JA, Asiago-Reddy E, Bartlett LC, et al. Mast cell activation and KSHV infection in Kaposi sarcoma. Clin Cancer Res. 2018;24:5085-97.

65. Stolze I, Hamm H. Lichen nitidus and lichen striatus. Hautarzt. 2018;69:121-6.

66. Vaughn RY, Smith JG. The treatment of lichen nitidus with astemizole. J Am Acad Dermatol. 1990;23:757-8. https://doi.org/10.1016/S01909622(08)81081-X.

67. Ocampo J, TornÉ R. Generalized lichen nitidus: report of two cases treated with astemizol. Int J Dermatol. 1989;28:49-51.

68. Gao F, Miyamoto M, Ogata H, Tsuboi R, Mitsuhashi Y. Generalized lichen nitidus in a Japanese girl. J Dermatol. 2012;39:185-7.

69. Al-Mutairi N, Hassanein A, Nour-Eldin O, Arun J. Generalized lichen nitidus. Pediatr Dermatol. $2005 ; 22: 158-60$.

70. D'Ovidio R, Rossi A, Di Prima TM. Effectiveness of the association of cetirizine and topical steroids in lichen planus pilaris-an open-label clinical trial. Dermatol Ther. 2010;23:547-52.

71. Mardones F, Shapiro J. Lichen planopilaris in a Latin American (Chilean) population: demographics, clinical profile and treatment experience. Clin Exp Dermatol. 2017;42:755-9.

72. Tavakolpour S, Mahmoudi HR, Abedini R, Kamyab Hesari K, Kiani A, Daneshpazhooh M. Frontal fibrosing alopecia: An update on the hypothesis of pathogenesis and treatment. Int J Women's Dermatol. 2019;5:116-23. https://doi.org/10.1016/j. ijwd.2018.11.003.

73. Greenwood R, Tring FC. Treatment of malignant acanthosis Nigricans with cyproheptadine. $\mathrm{Br} \mathrm{J}$ Dermatol. 1982;106:697-8.

74. Kashiwakura J-I, Otani IM, Kawakami T. Monomeric IgE and mast cell development, survival and function. Adv Exp Med Biol. 2011;716:29-46.

75. Medina V, Martinel D, Brenzoni P, Massari N, Carabajal E, Rivera E, et al. Histamine receptors as potential therapeutic targets for cancer drug development. Drug Dev Case Study Based Insight Mod Strateg. 2011:75-100.

76. Or CHR, Su HL, Lee WC, Yang SY, Ho C, Chang CC. Diphenhydramine induces melanoma cell apoptosis by suppressing STAT3/MCL-1 survival signaling and retards B16-F10 melanoma growth in vivo. Oncol Rep. 2016;36:3465-71.

77. Fritz I, Wagner P, Bottai M, Eriksson H, Ingvar C, Krakowski I, et al. Desloratadine and loratadine use associated with improved melanoma survival. Allergy Eur J Allergy Clin Immunol. 2020;75:7-10.

78. Pestelli E, Floriani I, Fabbri P, Caproni M. Cetirizine modulates adhesion molecule expression in a double-blind controlled study conducted in psoriatic patients. Int J Tissue React. 2003;25:1-8.

79. Capponi M, Maria Palleschi G, Falcos D, Papi C, Lotti T. Pharmacologic modulation by cetirizine of some adhesion molecules expression in psoriatic skin lesions. Int J Dermatol. 1995;34:510-3.

80. Pestelli E, Caproni M, Giomi B, Volpi W, Spallanzani A, Cardinali $\mathrm{C}$, et al. Cetirizine reduces the number of tryptase-positive mast cells in psoriatic patients: a double-blind controlled study. Int J Tissue React. 2001;23:97-103.

81. Moriyasu S, Yamamoto K, Kureyama N, Okamura K, Ikeda T, Yamatodani A. Involvement of histamine released from mast cells in acute radiation dermatitis in mice. J Pharmacol Sci. 2007;104:187-90.

82. Murakami R, Baba Y, Nishimura R, Furusawa M, Yokoyama T, Yamashita Y, et al. The effect of azelastine on acute radiation dermatitis in mice models. Int J Radiat Oncol Biol Phys. 1997;37:907-11.

83. Furusawa M, Baba Y, Murakami R, Yokoyama T, Uozumi H, Nishimura R, et al. Azelastine: its clinical application for radiation dermatitis. Radiat Med. 1996;14:151-4.

84. Kinoshita-Ise M, Shear NH. Diagnostic and therapeutic approach to scalp dysesthesia: a case series and published work review. J Dermatol. 2019;46: 526-30.

85. Hoss D, Segal S. Scalp dysesthesia. Arch Dermatol. 1998;134:327-30.

86. Sikand P, Shimada SG, Green BG, Lamotte RH. Sensory responses to injection and punctate application of capsaicin and histamine to the skin. Pain. 2011;152:2485-94.

87. Chi CC. Evidence-based dermatology. Dermatol Sin. 2013;31:2-6. https://doi.org/10.1016/j.dsi. 2012.06.002. 